\title{
Occupational asthma caused by palladium
}

\author{
M. Daenen*, Ph. Rogiers ${ }^{+}$, C. Van de Walle ${ }^{\star}$, F. Rochette*, M. Demedts*, B. Nemery*
}

\begin{abstract}
Occupational asthma caused by palladium. M. Daenen, Ph. Rogiers, C. Van de Walle, F. Rochette, M. Demedts, B. Nemery. (C)ERS Journals Ltd 1999.

ABSTRACT: Occupational exposure to complex platinum salts is a well-known cause of occupational asthma. Although there is evidence that platinum refinery workers may also be sensitized to other precious metals, such as palladium or rhodium, no instances of occupational asthma due to an isolated sensitization to palladium have been reported.

A case is reported of occupational rhinoconjunctivitis and asthma in a previously healthy worker exposed to the fumes of an electroplating bath containing palladium. There was no exposure to platinum.

Sensitization to palladium was documented by skin-prick tests. The skin-prick test was positive with $\mathrm{Pd}\left(\mathrm{NH}_{3}\right)_{4} \mathrm{Cl}_{2}$, but not with $\left(\mathrm{NH}_{4}\right)_{2} \mathbf{P d C l}_{4}$. Corresponding salts of platinum were all negative. A bronchial provocation test with $\mathrm{Pd}\left(\mathrm{NH}_{3}\right)_{4} \mathrm{Cl}_{2}(\mathbf{0 . 0 0 0 1 \%}$ for a total of $315 \mathrm{~s}$, followed by $0.001 \%$ for a total of $210 \mathrm{~s}$ ) led to an early decrease in forced expiratory volume in one second $(-35 \%)$. A similar exposure $(0.001 \%$ for a total of $16 \mathrm{~min}$ ) in an unrelated asthmatic gave no reaction.

This case shows that an isolated sensitization to palladium can occur and that respiratory exposure to palladium is a novel cause of metal-induced occupational asthma.

Eur Respir J 1999; 13: 213-216.
\end{abstract}

The metals of the platinum family include ruthenium ( $\mathrm{Ru}$, atomic number 44), rhodium ( $\mathrm{Rh}, 45)$, palladium $(\mathrm{Pd}$, 46), osmium (Os, 76), iridium (Ir, 77) and platinum (Pt, 78). These rare elements, often collectively called precious metals, are generally present together in sedimentary soils, with platinum being the most abundant. These metals are used for various applications, from jewellery to catalysts (platinum), electron microscopy (osmium), and various high-technology sectors, including the metallization of electronic parts [1].

Of all these precious metals, only platinum is known to be a cause of occupational asthma [2-6]. The strong sensitization potential of complex platinum salts has been well documented from numerous studies in workers from precious metal refineries [5-7]. Sensitization is generally considered to occur through a hypersensitivity reaction mediated by immunoglobulin $(\mathrm{Ig}) \mathrm{E}[8,9]$. This explains why skin-prick testing can be used for the detection of sensitization to platinum, both for surveillance purposes and 11]. Although positive skin tests to the other precious metals have been found to occur occasionally in platinum refinery workers, such sensitization was never found without concomitant sensitization to platinum [8] and no cases of occupational asthma due to precious metals other than platinum have been reported [3].

This study reports a case of occupational asthma (and rhinoconjunctivitis) due to an isolated sensitization to palladium in a worker who was not exposed to platinum. in the clinical diagnosis of platinum-induced asthma [7, 10, ${ }^{+}$A.Z. St-Lucas, Brugge, Belgium. ${ }^{\star}$ Siemens, Oostkamp, Belgium.

Correspondence: B. Nemery

Laboratorium voor Pneumologie

K.U. Leuven

Herestraat 49

Belgium

Fax 3216347124

Keywords: Bronchial provocation tests metals

occupational asthma

palladium

platinum

rhinitis

Received: January 301998

Accepted after revision August 41998
*Pneumology, K.U. Leuven, Belgium.

B-3000 Leuven

\section{Case report}

A 26 yr-old male was referred to the hospital with complaints of rhinoconjunctivitis and attacks of dyspnoea and chest tightness, with a duration of about 3 months. He had no significant previous medical history; he was a smoker, having smoked 10-12 cigarettes daily for about 10 yrs. There was no evidence for atopy or allergy.

The patient reported that his respiratory problems only occurred at work. He had been working for the past $7 \mathrm{yrs}$ in a factory where electromechanical components are made and assembled. He was responsible for the quality control of a galvanizing process on an assembly line and was, thus, exposed to the fumes of various electrolysis baths containing nickel, tin, palladium, lead and gold. There was no exposure to other metals (e.g. platinum). The patient had noticed that his symptoms occurred about $30 \mathrm{~min}$ after exposure to the fumes of just one electrolysis bath which contained ammonium hydroxide and palladium chloride. Self-measured peak-flow records were highly suggestive of obstructive episodes occurring only at work (data not shown). No medication had been prescribed. There were no dermal symptoms.

White blood cell count and composition were within normal limits; total serum IgE was $50 \mathrm{U} \cdot \mathrm{mL}^{-1}$ (normal value $<126 \mathrm{U} \cdot \mathrm{mL}^{-1}$ ) and serum antibodies (radioallergosorbent test (RAST)) against house dust mite, moulds, grasses, trees and herbs were negative. Pulmonary function tests were within normal limits [12] (forced vital capacity (FVC) $5.74 \mathrm{~L}$ (104\% predicted), forced expiratory volume in one 
second (FEV1) $4.65 \mathrm{~L}$, (101\% pred), total lung capacity (TLC) $8.33 \mathrm{~L}$ (111\% pred)). The provocative concentration of histamine causing a $20 \%$ fall in FEV1(PC20) showed a moderate degree of nonspecific airway hyperreactivity $(1.0$ $\left.\mathrm{mg} \cdot \mathrm{mL}^{-1}\right)$ (Cockcroft method).

To document sensitization to palladium, skin-prick tests were applied on the arm, using freshly prepared solutions of sodium hexachloroplatinate (IV) $\left(\mathrm{Na}_{2} \mathrm{PtCl}_{6}\right)$, ammonium tetrachloroplatinate (II) $\left(\left(\mathrm{NH}_{4}\right)_{2} \mathrm{PtCl}_{4}\right)$, palladium (II) chloride $\left(\mathrm{PdCl}_{2}\right)$ and tetraammine palladium (II) chloride (Pd $\left.\left(\mathrm{NH}_{3}\right)_{4} \mathrm{Cl}_{2}\right)$ (all purchased from Aldrich, Bornem, Belgium) in sterile saline. The starting concentrations were $0.0001 \%$ $(\mathrm{w} / \mathrm{v})$, with 10 -fold increasing steps up to $1 \%$ or the occurrence of a weal within $15 \mathrm{~min}$ of applying the solution. The tests were negative for the two platinum salts, possibly positive for $\mathrm{PdCl}_{2}$ (at $0.1 \%$ ) and definitely positive, i.e. causing a weal of $>3 \mathrm{~mm}$ diameter, for $\mathrm{Pd}\left(\mathrm{NH}_{3}\right)_{4} \mathrm{Cl}_{2}$ (at $0.001 \%)$.

To confirm the causal role of palladium, a specific bronchial provocation test was performed, according to existing recommendations [13], using nebulized saline on a control day and, on the next day, the same $\mathrm{Pd}\left(\mathrm{NH}_{3}\right)_{4} \mathrm{Cl}_{2}$ solutions as for the skin tests. After an exposure to $0.0001 \%$ for 5 , $10,30,90$, and $180 \mathrm{~s}$ (with $10 \mathrm{~min}$ between each exposure), followed by $0.001 \%$ for $10,10,10,30,30,30$, and $90 \mathrm{~s}$, an early bronchospastic reaction occurred, with a maximum FEV1 decrease of 35\% (fig. 1). The patient complained of dyspnoea and was found to be wheezing on
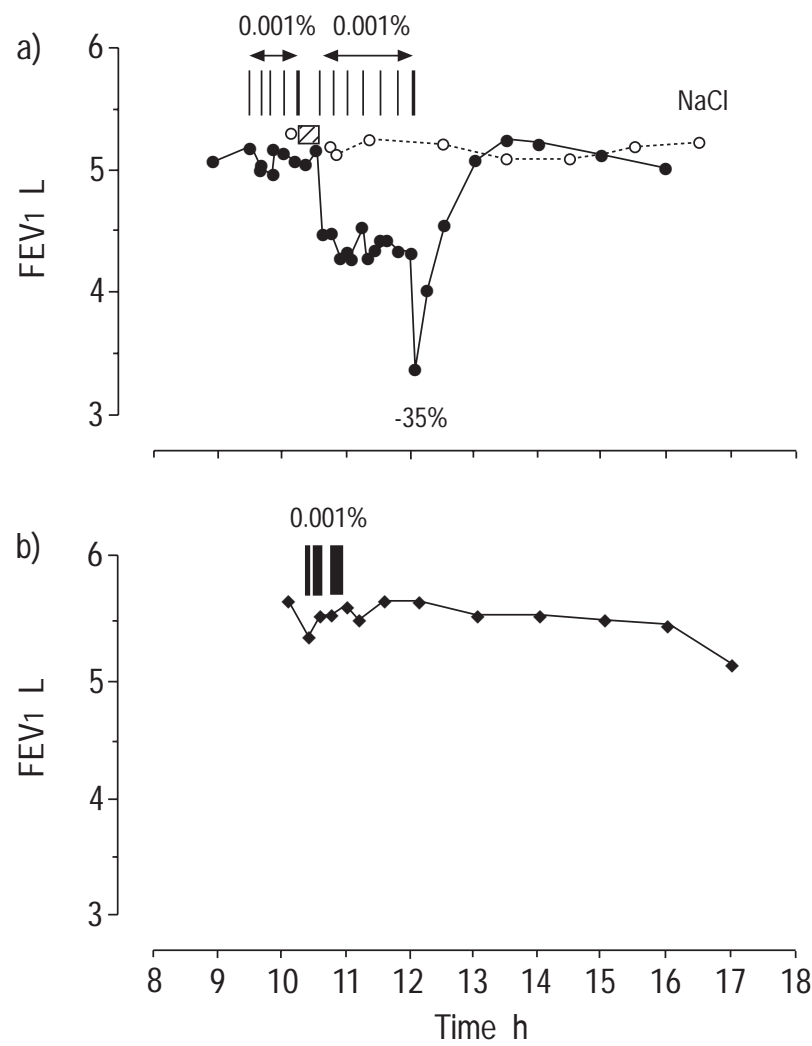

Fig. 1. - Time course of forced expiratory volume in one second (FEV1) following exposure to nebulized saline $(\mathrm{O})$ or $\left.\mathrm{Pd}\left(\mathrm{NH}_{3}\right)_{4} \mathrm{Cl}_{2}\right)(\bullet)$ in a) a patient with occupational asthma and b) a control subject. $\mathbb{Z}$ : exposure to saline. The successive exposures to $\mathrm{Pd}\left(\mathrm{NH}_{3}\right)_{4} \mathrm{Cl}_{2}$ are indicated by vertical lines $(5-180 \mathrm{~s}$ in the patient, $1-10 \mathrm{~min}$ in the control subject). The time scale is given as absolute time of day. auscultation. The FEV1 improved spontaneously and there was no late reaction. A histamine test repeated $4 \mathrm{~h}$ after the end of the bronchial provocation test showed no change (PC20 $1.2 \mathrm{mg} \cdot \mathrm{mL}^{-1}$ ). There were no changes in peripheral leukocytes after the test.

To confirm the specificity of the response, a second person submitted to a bronchial challenge test with aerosolized $\mathrm{Pd}\left(\mathrm{NH}_{3}\right)_{4} \mathrm{Cl}_{2}$. This person, a male nonsmoker of similar age with no history of occupational exposure to precious metals, suffers from mild-to-moderate asthma (histamine PC20 $0.4 \mathrm{mg} \cdot \mathrm{mL}^{-1}$ ) due to IgE-mediated house dust mite allergy (positive skin test and RAST). He was exposed to a $0.001 \%$ concentration of $\mathrm{Pd}\left(\mathrm{NH}_{3}\right)_{4} \mathrm{Cl}_{2}$ for 1,5 and $10 \mathrm{~min}$. There were no symptoms or significant (immediate or delayed) changes in FVC, FEV1 or peak expiratory flow (PEF), monitored for up to $12 \mathrm{~h}$ after exposure (fig. 1).

The patient was relocated to another job within the same factory, but in a different hall, and he has been asymptomatic since then, although he reported that he could still "feel" the problem when he occasionally went into the immediate vicinity of his former workplace.

At the request of the reviewers, skin-prick tests were repeated more than $1 \mathrm{yr}$ later in order to verify the possibility of a concomitant sensitization to nickel. In a first series, the following compounds were tested (freshly prepared solutions of $0.001-1 \%$ in sterile saline): $\mathrm{Na}_{2} \mathrm{PtCl}_{6}$, $\left(\mathrm{NH}_{4}\right)_{2} \mathrm{PtCl}_{4}$, ammonium hexachloropalladate (IV) $\left(\mathrm{NH}_{4}\right)_{2}$ $\mathrm{PdCl}_{6}$ ) (Fluka, Buchs, Switzerland), ammonium tetrachloropalladate (II) $\left(\left(\mathrm{NH}_{4}\right)_{2} \mathrm{PdCl}_{4}\right)$ (Fluka), ammonium hexachlororhodate (III) $\left(\left(\mathrm{NH}_{4}\right)_{3} \mathrm{RhCl}_{6}\right)$ (Fluka), nickel(II) chloride $\left(\mathrm{NiCl}_{2}\right)$ (UCB, VEL, Leuven, Belgium) and cobalt (II) chloride $\left(\mathrm{CoCl}_{2}\right)$ (UCB). None of these tests gave a positive response, including, to the authors' surprise, the two palladium compounds. Therefore, a second series of skin testing was performed, using the following compounds in the same range of concentrations: $\left(\mathrm{NH}_{4}\right)_{2} \mathrm{PtCl}_{4}$, tetraamine platinum (II) chloride ( $\left.\mathrm{Pt}\left(\mathrm{NH}_{3}\right)_{4} \mathrm{Cl}_{2}\right)$ (Aldrich), $\left(\mathrm{NH}_{4}\right)_{2}$ $\mathrm{PdCl}_{4}$ and $\mathrm{Pd}\left(\mathrm{NH}_{3}\right)_{4} \mathrm{Cl}_{2}$. This time there was a clear positive response to the last (and only the last) agent (at $0.01 \%$ ), which was the chemical that had been tested in the first instance. All skin tests were negative in the control subject.

\section{Discussion}

There was no doubt that this patient had asthma (and rhinoconjunctivitis) as a result of his exposure to palladium-containing fumes at work. The clinical history and time course of symptoms and lung function were highly suggestive of occupational asthma and a specific bronchial provocation test using a complex palladium salt was convincingly positive. Although the patient only had immediate bronchospastic reactions and no delayed asthmatic reactions with evening or nightly symptoms, simple irritation can be ruled out on the basis of the history and the positive skin-prick tests, as well as the negative bronchial challenge in a control asthmatic. On the basis of the skinprick test results, it is reasonable to hypothesize that this asthma is caused by an immediate hypersensitivity reaction against palladium, as is the case for asthma caused by complex salts of platinum, although no other immunological data, such as specific IgE, were available to substantiate this theory. 
The sensitivity appeared to be highly specific to the type of palladium salt tested, since $\mathrm{Pd}\left(\mathrm{NH}_{3}\right)_{4} \mathrm{Cl}_{2}$ gave a positive skin response, whereas $\left(\mathrm{NH}_{4}\right)_{2} \mathrm{PdCl}_{4}$ did not. This difference between two palladium salts, even though they have similar oxidation states, underscores the importance of speciation in metal toxicology [2]. However, it was pure serendipity that led to the "right" agent being chosen for the initial testing of this patient. That choice was not the most sensible one in view of the literature on platinum. Indeed, Cleare et al. [14] assessed the reactivity to an extensive range of platinum salts in refinery workers and found positive reactions to $\left(\mathrm{NH}_{4}\right)_{2} \mathrm{PtCl}_{6}$ and no reaction to $\mathrm{Pt}\left(\mathrm{NH}_{3}\right)_{4} \mathrm{Cl}_{2}$. Similarly, $\mathrm{Na}_{2} \mathrm{PtCl}_{6}$ and $\mathrm{Na}_{2} \mathrm{PtCl}_{4}$ were confirmed to be highly immunogenic when tested in the popliteal lymph node assay in mice, whereas $\mathrm{Pt}\left(\mathrm{NH}_{3}\right)_{4} \mathrm{Cl}_{2}$ proved to be inert [15]. Thus, in the case of platinum, allergy-eliciting compounds are confined to a very small group of ionic complexes containing reactive halogen ligands [14] and this justifies the use of chloroplatinic acid or the sodium or ammonium salts of tetrachloroplatinate (II) or hexachloroplatinate (IV) to document allergy for platinum salts. The chemical and biological basis for the selectivity of the tetraammine complex salt of palladium in this patient remains elusive.

Previously, BiAgINI et al. [8] demonstrated the presence of both heat-stable/short-term and heat-labile/long-term sensitizing antibodies to both platinum $\left(\left(\mathrm{NH}_{4}\right)_{2} \mathrm{PtCl}_{6}\right)$ and palladium $\left(\left(\mathrm{Na}_{2} \mathrm{PdCl}_{4}\right)\right)$, indicating that the immune response generated by these compounds is heterogeneous [8]. They also found a positive passive cutaneous anaphylaxis response to palladium in nonhuman primates, using sera from palladium-exposed workmen. Whether or not this could be ascribed to a palladium-specific allergy response, rather than to a palladium-platinum cross-reactivity or platinum contamination, was unclear. Other authors have also described occasional positive skin-prick tests to salts of palladium or other precious metals but, in contrast to the present patient, this never occurred without concomitant sensitization to platinum [9].

To the authors' knowledge, no cases of palladiumrelated occupational asthma have ever been reported. However, in the dental and dermatological literature, there are a number of reports on contact allergy to palladium in cases associated with oral symptoms or nonmucosal dermatitis. Thus, the possible role of palladium (and other metals) has been investigated in patients with oral contact reactions related to dental prostheses [16-18]. Palladium sensitization, as shown by a positive patch test to palladium chloride, proved to be relatively frequent (up to $8 \%$ in a group of unselected patients) and was preceded only by nickel $[17,19]$. Patch tests are generally considered to reflect delayed hypersensitivity reactions and it is not known whether some of these patients also had positive skin prick tests, i.e. immediate allergy, against palladium. In an isolated case report [20], an older patient with stomatitis and an isolated positive patch test for palladium, was described as having developed new-onset asthmatic symptoms due to a palladium-containing dental prosthesis.

In the quoted studies, the vast majority of palladiumsensitized subjects also had positive patch test reactions to nickel $[21,22]$. This relationship between palladium and nickel is interesting because these metals belong to the same group (VIII) in the periodic table and they have a similar general chemistry. The concomitant patch test reac- tions were usually explained by previous exposure. The possibility of nickel contamination of the palladium salt had already been ruled out by chemical analysis [23]. More recently, animal models could demonstrate a true crossreactivity to nickel after sensitization with palladium [24]. Similarly, a cross-reactivity to cobalt was seen, following induction with rhodium. However, no cross-reactivity between chromium (group VI) and cobalt (group VIII) could be demonstrated [23]. These data in guinea-pigs indicate that cross-reactivity among the transition metals may be restricted to groups but not to periods in the periodic table of elements. This might also explain the possibility of cross-reactivity between platinum and palladium (both group VIII). However, the present case clearly indicates that this does not necessarily apply in all subjects, since the skin tests were negative for nickel and platinum.

In conclusion, this case of palladium-induced asthma suggests that palladium should be added to the list of metallic compounds that can cause occupational asthma.

\section{References}

1. Wataha JC, Hanks CT. Biological effects of palladium and risk of using palladium in dental casting alloys. $J$ Oral Rehab 1996; 23: 309-320.

2. Nemery B. Metal toxicity in the respiratory tract. Eur Respir J 1990; 3: 202-219.

3. Bernstein IL, Brooks SM. Metals. In: Bernstein IL, ChanYeung M, Malo JL, Bernstein DI, eds. Asthma in the Workplace. New York, Dekker, 1993; pp. 459-479.

4. Orbaek P. Allergy to the complex salts of platinum. A review of the literature and three case reports. Scand $J$ Work Environ Health 1982; 8: 141-145.

5. Merget R, Schultze-Werninghaus G, Muthorst T, Friedrich W, Meier-Sydow J. Asthma due to the complex salts of platinum - a cross-sectional survey of workers in a platinum refinery. Clin Allergy 1988; 18: 569-580.

6. Hughes EG. Medical surveillance of platinum refinery workers. J Soc Occup Med 1980; 30: 27-30.

7. Baker DB, Gann PH, Brooks SM, Gallagher J, Bernstein IL. Cross-sectional study of platinum salts sensitization among precious metals refinery workers. Am J Ind Med 1990; 18: 653-664.

8. Biagini RE, Bernstein IL, Gallagher JS, Moorman WJ, Brooks S, Gann PH. The diversity of reaginic immune responses to platinum and palladium metallic salts. $J$ Allergy Clin Immunol 1985; 76: 794-802.

9. Murdoch RD, Pepys J, Hughes EG. IgE antibody responses to platinum group metals: a large scale refinery survey. Br J Ind Med 1986; 43: 37-43.

10. Brooks SM, Baker DB, Gann PH, et al. Cold air challenge and platinum skin reactivity in platinum refinery workers. Chest 1990; 97: 1401-1407.

11. Merget R, Schultze-Werninghaus G, Bode F, Bergmann EM, Zachgo W, Meier-Sydow J. Quantitative skin prick and bronchial provocation tests with platinum salt. $\mathrm{Br} J$ Ind Med 1991; 48: 830-837.

12. Quanjer $\mathrm{PhH}$, ed. Standardized lung function testing. Eur Respir J 1993; 6: Suppl. 16, 1-95.

13. Cartier A, Malo J-L. Occupational challenge tests. In: Bernstein IL, Chan-Yeung M, Malo JL, Bernstein DI, eds. Asthma in the Workplace. New York, Dekker, 1993; pp. 215-247.

14. Cleare MJ, Hughes EG, Jacoby B, Pepys J. Immediate (type I) allergic responses to platinum compounds. Clin Allergy 1976; 6: 183-195. 
15. Schuppe H-C, Kulig J, Kühn U, et al. Immunostimulatory effects of platinum compounds: correlation between sensitizing properties in vivo and modulation of receptormediated endocytosis in vitro. Int Arch Allergy Immunol 1997; 112: 125-132.

16. Vilaplana J, Romaguera C, Cornellana F. Contact dermatitis and adverse oral mucous membrane reactions related to the use of dental prostheses. Contact Dermatitis 1994; 30: 80-84.

17. Aberer W, Holub H, Strohal R, Slavicek R. Palladium in dental alloys - the dermatologists' responsibility to warn? Contact Dermatitis 1993; 28: 163-165.

18. Koch P, Bahmer FA. Oral lichenoid lesions, mercury hypersensitivity and combined hypersensitivity to mercury and other metals: histologically proven reproduction of the reaction by patch tests with metal salts. Contact Dermatitis 1995; 33: 323-328.

19. De Fine Olivarius F, Menné T. Contact dermatitis from metallic palladium in patients reacting to palladium chloride. Contact Dermatitis 1992; 27: 71-73.

20. Kütting B, Brehler R. Klinisch relevante solitäre Palladiumallergie. Hautarzt 1994; 45: 176-178.

21. Uter W, Fuchs T, Hausser M, Ippen H. Patch test results with serial dilutions of nickel sulfate (with and without detergent), palladium chloride, and nickel and palladium metal plater. Contact Dermatitis 1995; 32: 135-142.

22. Todd DJ, Burrows D. Patch testing with pure palladium metal in patients with sensitivity to palladium chloride. Contact Dermatitis 1992; 2627: 327-331.

23. Lidén C, Wahlberg JE. Cross-reactivity to metal compounds studied in guinea pigs induced with chromate or cobalt. Acta Derm Venereol 1994; 74: 341-343.

24. Wahlberg JE, Boman AS. Cross-reactivity to palladium and nickel studied in the guinea pig. Acta Derm Venereol 1992; 72: 95-97. 